\title{
Redactioneel
}

\section{Zicht op het doel: wendbaar vooruit}

\author{
Jeroen Goudsmit en Arnt Mein*
}

Als de wereld om je heen verandert, blijf je dan hetzelfde doen wat je al deed? Het vermogen om zich aan te passen aan veranderende omstandigheden is een eigenschap van elke gezonde organisatie. De wereld anno 2021 ziet er behoorlijk anders uit dan die van een jaar geleden. In dit nummer leest u hoe verschillende toezichthouders omgaan of zouden moeten omgaan met deze veranderingen. Wendbaarheid en het scherp zicht houden op het maatschappelijke doel van het toezicht vormen de rode draad.

Om te beginnen doen Fiore Geelhoed, Sophie Benerink en Martine Ceton verslag van hun onderzoek naar de naleving van regels in de veehouderij. Een sector onder druk van ontwikkelingen (o.m. mestfraude, voedselveiligheid, uitstoot van stikstof en dierenwelzijn) die nopen tot ingrijpende veranderingen. $\mathrm{Zij}$ hebben onderzocht hoe veehouders zich in deze omstandigheden staande houden, meer in het bijzonder in hoeverre zij erin slagen de vele op hen van toepassing zijnde voorschriften na te leven. Welke overwegingen en motieven hanteren zij in dit verband? De onderzoekers stellen vast dat in verschillende sectoren de veehouders de regels overtreden. Een samenspel van economische motieven, persoonlijke en sociale normen draagt daaraan bij. Voor toezichthouders betekent dit dat zij proactief en scherp zicht moeten houden op misstanden in de gehele sector, en zich minder zouden moeten fixeren op risicobedrijven en door derden gesignaleerde misstanden. Ook zouden zij zich moeten bezinnen op de vraag hoe hun optreden op de veehouders overkomt.

Dr. J. Goudsmit is kerndocent Compliance \& Integriteitmanagement aan de Vrije Universiteit Amsterdam, compliance officer ter bestrijding van witwassen, terrorismefinanciering en sanctie-overtredingen bij de Rabobank en redactielid van Tijdschrift voor Toezicht. Mr. dr. A. Mein is lector Legal Management aan de Hogeschool van Amsterdam, faculteit Maatschappij en Recht en redactielid van Tijdschrift voor Toezicht.
De coronacrisis vraagt om wendbaarheid bij toezichthouders: wat vóór de crisis goed toezicht was, hoeft dat nu niet meer te zijn. Lisette van der Hel en Sjoerd Goslinga bieden in hun bijdrage uit het veld inzicht hoe de Belastingdienst rekening houdt met deze crisis. De fiscale nalevingsbereidheid van bedrijven en burgers kan worden beïnvloed door uiteenlopende factoren, zoals de gepercipieerde verminderde controlekans en veranderende sentimenten ten aanzien van solidariteit en institutioneel vertrouwen. Van der Hel en Goslinga delen de crisis op in drie fases en bespreken de verschillende elementen die van belang zijn voor het fiscaal toezicht in en na de crisistijd. Ze pleiten tegen een legalistische opstelling en voor het monitoren of wetgeving wel uitpakt zoals ze bedoeld is én bijdraagt aan de beoogde maatschappelijke doelen.

De volgende etappe in onze toezichtsinterviewestafette liep via De Nederlandsche Bank (DNB), waar de redactie sprak met Else Bos, sinds 1 juli 2018 toezichtdirecteur en voorzitter toezicht. In het gesprek wordt ingegaan op de grote uitdagingen voor DNB, in het bijzonder hoe de coronacrisis raakt aan haar mensen, de manier waarop toezicht wordt gehouden en de klap die de economie heeft gekregen. Zij benadrukt het belang voor toezichthouders om te denken vanuit root causes, met governance, gedrag en cultuur als cruciale spil waar je langdurig aandacht aan moet besteden. Denk hier bijvoorbeeld aan de mentale wendbaarheid van bestuurders: zien ze of wat ze doen nog wel past bij wat er om hen heen gebeurt?

Wendbaarheid is ook het stille sleutelbegrip in Jet Bussemakers column over de veranderingen in het toezicht op de zorg, zoals die zijn ontstaan tijdens de coronacrisis. Zij signaleert toezichthouders die scherp zicht hebben gehouden op de beoogde maatschappelijke doelen van onderliggende regelgeving, zoals de NZa die de regels rondom het registreren van zorg op afstand heeft verruimd. Ook het Centrum Indicatiestelling Zorg 
(CIZ) en de Inspectie Gezondheidszorg en Jeugd (IGJ) toonden in haar ogen wendbaarheid in de uitvoering van hun toezicht- en reguleringsfunctie. Bussemaker ziet vertrouwen boven regelgeving als centraal thema en pleit ervoor om verdere stappen in deze richting te zetten.

Tot slot onze vaste rubrieken waarin een belangwekkende rechterlijke uitspraak of een relevant boek worden besproken. Zo markeert Christien Saris nog eens duidelijk de grens tussen toezicht en opsporing aan de hand van een arrest van de Hoge Raad van 30 juni 2020. De afbakening tussen toezicht en handhaving is niet alleen voer voor theoretici, maar ook van groot praktisch belang voor toezichthouders: welke bevoegdheden mogen in welk kader worden gebruikt? Hadewich van Kempen bespreekt het boek Morality and the Regulation of Social Behavior van Naomi Ellemers (2018). In dit boek zet zij uiteen hoe integriteit, groepen en gedrag met elkaar samenhangen. Verplichte kost voor toezichthouders die geïnteresseerd zijn in het normbesef van (groepen van) ondertoezichtgestelden. Het boek benadrukt het belang van een gedifferentieerde handhavingsstrategie: wendbaarheid. 